\title{
Experience of the spouse of a woman with breast cancer undergoing chemotherapy: a qualitative case study
}

\author{
Experiência do cônjuge diante da mulher com câncer de mama e em quimioterapia: estudo de \\ caso qualitativo
}

\section{Experiencia del cónyuge de una mujer con cáncer de mama en quimioterapia: estudio de caso cualitativo}

\author{
Rhyquelle Rhibna Neris ${ }^{1}$ \\ Márcia Maria Fontão Zago ${ }^{1}$ \\ Maria Ângela Ribeiro ${ }^{2}$ \\ Juliana Pena Porto ${ }^{2}$
}

Anna Cláudia Yokoyama dos Anjos ${ }^{2}$

1. Universidade de São Paulo.

Ribeirão Preto, SP, Brasil.

2. Universidade Federal de Uberlândia.

Uberlândia, MG, Brasil.
Corresponding author:

Rhyquelle Rhibna Neris.

E-mail: rhyquelle@usp.br

Submitted on $02 / 16 / 2018$.

Accepted on 05/19/2018.

DOI: 10.1590/2177-9465-EAN-2018-0025

\begin{abstract}
Objective: To identify the meaning attributed to the experience of a spouse of a woman with breast cancer undergoing chemotherapy. Methods: Descriptive study, with a theoretical-methodological orientation based on medical anthropology and utilizing an ethnographic case study strategy. Data were collected through semi-structured interviews and participant observation. Results: The meanings revealed that the diagnosis cause suffering. Chemotherapy was seen as giving hope of healing the wife's cancer. During this process, the spouse had to deal with the strong adverse effects of the treatment and subordinate to his wife to reduce the conflict experienced by the couple, which violated the rules of his masculinity. Religion and family were important support networks on this path. Final considerations and implications for practice: The results showed the importance of considering cultural aspects of spouses when they are faced with disease in their wives. The way spouses deal with breast cancer will depend on their cultural systems. Nursing care must be comprehensive and extend to spouses whose wives have breast cancer.
\end{abstract}

Keywords: Breast neoplasms; Spouses; Medical anthropology; Case reports.

\section{Resumo}

Objetivo: Identificar os sentidos atribuídos à experiência do cônjuge diante da mulher com câncer de mama e em quimioterapia. Método: Estudo descritivo, com orientação teórico-metodológica da antropologia médica e estratégia de estudo de caso etnográfico. Os dados foram coletados utilizando entrevistas semiestruturadas e observação participante. Resultados: Os sentidos revelaram um diagnóstico sofrido. A quimioterapia foi recebida como esperança de cura para o câncer da esposa. $\mathrm{Na}$ trajetória, precisou lidar com os fortes efeitos adversos do tratamento e ainda se subordinar à esposa para diminuir os conflitos do casal, violando então as regras da sua masculinidade. Nesse percurso, a religião e a família foram importantes redes de apoio. Considerações finais e implicações para prática: Os resultados evidenciaram a importância de se considerar os aspectos culturais do parceiro diante do adoecimento da esposa, a forma como lidará com o câncer de mama dependerá do seu sistema cultural. A assistência de enfermagem deve ser integral e estender o cuidado também ao cônjuge da mulher que tem câncer de mama.

Palavras-chave: Neoplasias da mama; Cônjuges; Antropologia médica; Estudos de casos.

\section{Resumen}

Objetivo: Identificar sentidos atribuidos a experiencia del cónyuge de mujer con cáncer de mama en quimioterapia. Método: Estudio descriptivo, orientación teórico-metodológica de antropología médica, estudio de caso etnográfico. Datos recolectados mediante entrevistas semiestructuradas y observación participante. Resultados: Se revela un diagnóstico sufrido. La quimioterapia fue recibida como esperanza de cura al cáncer de la esposa. Durante el tratamiento debió lidiar con los fuertes efectos adversos, e inclusive, subordinarse a la esposa para disminuir los conflictos de pareja, violando las normas de su masculinidad. Durante ese período, religión y familia constituyeron importantes redes de apoyo. Consideraciones finales e implicaciones para práctica: Los resultados evidenciaron la importancia de considerar aspectos culturales del compañero ante el padecimiento de la esposa, la forma en que enfrentará al cáncer de mama dependerá de su sistema cultural. Se requerirá atención de enfermería integral, extendiendo el cuidado al cónyuge de la mujer con cáncer de mama.

Palabras clave: Neoplasias de la Mama; Esposos; Antropología Médica; Informes de Casos. 


\section{INTRODUCTION}

It is estimated that there will be 59,700 new cases of breast cancer in each year of the 2018-2019 biennium in Brazil, with an estimated risk of 56.33 cases per 100,000 women. Excluding non-melanoma skin tumors, this type of cancer is the most frequent in women living in the South, Southeast, Central-West, and Northeast regions of Brazil. ${ }^{1}$

Among the therapies for breast cancer, because of its systemic nature, chemotherapy is the one which causes more adverse reactions, and a consequent decrease in the quality of life of patients. The impacts of the disease extend to the lives of families and couples, with repercussions in all aspects of their routines. ${ }^{2,3}$

In this context, families assume greater importance, because they play a relevant collaborative role in coping with the disease, treatments, and their effects. Studies have indicated that families are considered the main source of psychological, emotional, and social support in this situation. Thus, cancer can be considered a family disease, which, when diagnosed in one member, has the power to change the life experience of the other family members, including spouses. ${ }^{4,5}$

The repercussions of cancer in the context of patients families include financial concerns, problems at work, and relationship issues. In addition, cancer can interfere with marriage, and couples may divorce as a consequence of this additional burden and changes in the family. ${ }^{6}$

Being the spouse of a woman with cancer has been described in the literature as living in the shadow of the disease. Recent investigations have shown that one year after the cancer diagnosis of their wives, spouses had a significantly higher rate of mood disorders, reactions to the severe stress, and ischemic cardiac disease. Anxiety levels become high, and uncertainty about the future and the possible recurrence of cancer unsettle the lives of these spouses. They feel vulnerable in the fact of the disease and cannot handle the suffering of their wives. ${ }^{4,5}$

A integrative literature review focused on the perceptions and experiences of spouses of women with breast cancer and the ways in which they cope with difficulties revealed that few Brazilian or international studies have addressed the proposed objective, pointing to a gap in knowledge of this area. The findings of this review stressed the need to invest in research with a stronger focus on this topic. ${ }^{5}$

Considering that sociocultural influences have a significant impact on knowledge, behavior, ways to deal with different situations in life, and the meanings that spouses associate with the disease experience, the objective of the present study was to answer the following question: How do spouses of women with breast cancer define the meanings of the experience of chemotherapy of their wives? The goal of the present study was to identify the meanings associated with the experience of spouses of women with breast cancer undergoing chemotherapy.

\section{METHODS}

This was a descriptive and qualitative study with a theoretical-methodological orientation based on medical anthropology and utilizing an ethnographic case study strategy.

Medical anthropology aims to integrate health, disease, and culture. It considers health as the result of interaction between biological and cultural factors. According to the interpretative concept, culture is a symbolic and public system centered on individuals, who use it to interpret their world and actions it consists of beliefs, values, symbols, standards, and practices. Interaction between biological and cultural aspects is construed as the structuring element of the experience. ${ }^{7}$

The instrumental case study method was employed to develop the present qualitative investigation, because it provides an extended observation of cases under analysis. The details of this method allow studies to consider various dimensions and pay attention to the most central and intimate aspects, using researchers' skills to understand certain experiences. The focus of a case studies is analysis of how and why certain characteristics of the case are shaped by the context. This method allows the participation in multiple cases or just one, and the examination in different moments of the experience. ${ }^{8,9}$

The present study examined the case of the spouse of a woman with breast cancer undergoing chemotherapy. The spouse was the person who most frequently accompanied the patient, who was being treated in an oncology service, and he was invited to participate in the investigation. The initial contact occurred in the oncology outpatient facility of a teaching hospital in the countryside of the state of Minas Gerais, Brazil, after a nursing appointment. The subject was selected based on the following inclusion criteria: being the spouse of a woman with breast cancer undergoing the initial phases of chemotherapy, regardless of the chemotherapy scheme and cancer stage; being 18 years old or older; being married to or in a commonlaw marriage with the woman; having lived with the wife in the same house for at least one year; and agreeing to participate in the study and have the interviews recorded. After accepting the invitation to participate in the investigation, the individual signed a free and informed consent form. He was given a fictitious name to guarantee his anonymity.

The present study followed ethical principles for research with human subjects and was approved by the research ethics committee (CAAE № 40672614.5.0000.5152).

Data were collected by one of the researchers, in the oncology outpatient facility of the institution and the family household, from March to September 2015. Six interviews were carried out, with an average duration of 30 minutes, at difference points of the experience, to give the study greater.

The techniques used in data collection were observation, notes in a field journal, and recorded semi-structured interviews. These were guided by the following questions: How does it feel to share a life with a wife with cancer who is undergoing 
therapy? How do you handle the situations that arise? Tell me about difficulties you have experienced and what you have done to overcome them. Have you received help from anybody?

Data were analyzed according to the inductive thematic analysis technique. Initially, the transcriptions of the interviews and the records in the field journal were grouped into a single document by researchers. After reading all of the material, categorization of the relevant aspects of the data and classification into subjects were carried out, with a focus on the objective of the study. The subject is a level of standard answer, which interprets the meaning within the data set, regarding the research questions. ${ }^{10}$

Explanatory models were used to describe how the spouse of a woman with breast cancer builds his experience during chemotherapy. These patterns are construed as cultural models into which people fit the disease experience, giving it a meaning for both themselves and members of their cultural context. The meanings are the descriptions of the process experienced by participants, with their ideas and actions regarding the disease and chemotherapy, explained through motivations and justifications extracted from their cultural history. ${ }^{11,12}$

\section{RESULTS}

\section{Context of the case}

The context is presented in order to foster understanding of the case. The participant, whom we will call Francisco, was 41 years old, married, white, and had incomplete higher education. He worked as a public employee in hydrometry, with an eight-hour working day. His job generated an income of approximately five minimum wages, with which he supported his family. He was a practicing Mormon in a local church, where he held a leadership position and was assiduous in carrying out his responsibilities.

His wife, whom we will call Aline, was 39 years old and a housewife. She was responsible for managing and performing the tasks involving the household and children, including their school activities, before she became ill. In January 2014 she noticed a nodule in her left breast and immediately sought medical care, but a biopsy was not carried until December 2014. The anatomopathological result was compatible with a Grade 2 invasive ductal carcinoma. Because of its stage (T3NOMO), the patient's young age, and other factors identified in the examinations, neoadjuvant chemotherapy was proposed, with a protocol including four cycles of doxorubicin + cyclophosphamide (a combination is known as AC chemotherapy) and four cycles of docetaxel, with a 21-day interval between cycles. The chemotherapy treatment was carried out between February and June 2015, and was suspended because of medullary toxicity in the penultimate cycle.

The couple had been married for 21 years and had four children, whose ages ranged from 5 to 16 years old. The whole family lived in the house they owned.

\section{Meaning units}

Four meaning units were identified from the collected data. These units are depicted in Figure 1.
Figure 1. Meanings representative of the experience of the spouse of a woman with breast cancer undergoing chemotherapy. Source: Designed by the authors.

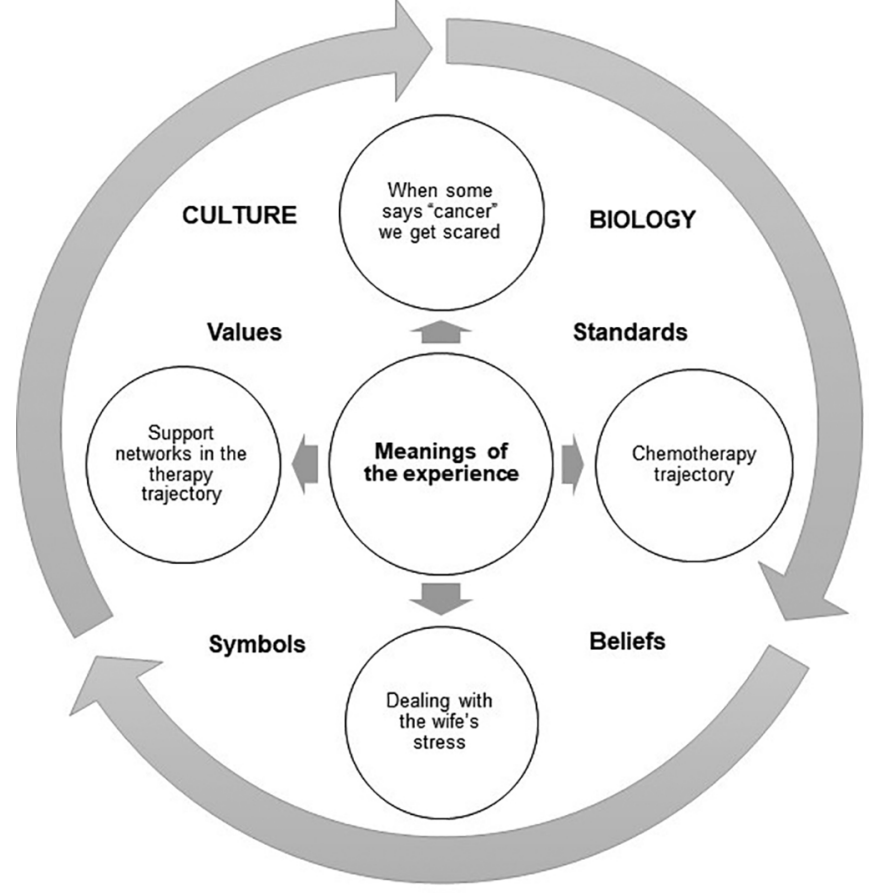

\section{When someone says "cancer" we get scared}

In the explanatory model of Francisco, the first sign of his wife's breast cancer was the appearance of a lump. The search for medical care began immediately after the perception of the breast change, but according to the information provided by him, there was a long period until the diagnosis, given that his wife's condition was evaluated by several healthcare professionals, who did not associate the symptoms with the possibility of breast cancer:

One of the doctors thought that it could have been from a blow to her breast, it looked like a trauma [...] Another doctor just told us to apply hot pads because it could be a swollen gland. ( $1^{\text {st }}$ interview)

Several examinations were carried out to define the diagnosis:

She had appointments with a gynecologist and a mastologist, and unfortunately, I do not know why, they could not identify the problem. The fifth doctor was the one who requested a biopsy and found out it was cancer. (his eyes teared up) ( $1^{\text {st }}$ interview)

The diagnosis was received by the participant with sadness, and her experienced "a shock" in his life reality, given that cancer has a cultural connotation of being overwhelming, severe, and incurable: 
When someone says" cancer" we get scared, we know it is serious, really serious. It is a disease that has no cure, it is hard to treat. ( $2^{\text {nd }}$ interview)

After the diagnosis, he looked for an explanation, which allowed him to create a new meaning for the experience finding out about the cancer.

It is a shocking situation, I know that everything in life has a purpose. Even if it is something painful, something hard to live with, we have to learn something from it. ( $1^{\text {st }}$ interview)

These excerpts reveal that the meaning associated with the cancer diagnosis was one of shock and sadness, because the disease is considered incurable and thought to involve suffering and the possibility of death. The experiences of relatives and people from his social circle reinforced the common sense of this meaning.

\section{The chemotherapy process}

After the impact of the diagnosis, considering the need for systemic treatment, the medical team suggested neoadjuvant chemotherapy. According to the lay explanatory model of the participant, chemotherapy:

Is a treatment that aims to cure this disease, cancer. That's the main objective of using this medicine, this drug that chemotherapy is. (5 $5^{\text {th }}$ interview)

The news about chemotherapy was received with hope for the "chance of cure, "and provided motivation for the strength to go on:

We are happy because there is a treatment. When I heard that she would undergo chemotherapy I was relieved. We can see results, the tumor is shrinking, and we are very hopeful about the cure. ( $5^{\text {th }}$ interview)

In Francisco's narrative, the acceptance and valorization of the proposed medical treatment are patent. For him, this was the best option, even if it caused changes and discomfort in his and his wife's lives:

Her treatment has been difficult. Initially, she had nausea and now she has strong pain. It is complicated, but it is what I say to her, she has to do it, no matter what it can cause. We have to be thankful that there is a treatment. $\left(5^{\text {th }}\right.$ interview)

During the chemotherapy process, he mentioned difficulties dealing with the adverse effects and repercussions of the treatment. He also reported lack of information from healthcare professionals. Thus, every new chemotherapy cycle was an "unknown situation", a "new surprise." All the problems they faced, mainly those resulting from adverse reactions and their levels of intensity, together with lack of guidance, made the participant question if they really originated from the treatment:

We wondered: Is it really chemotherapy that is causing this pain? I do not remember her being oriented about that. Everything that happens to her is a surprise, it is becoming an unknown situation. ( $3^{\text {rd }}$ interview)

His previous cultural knowledge of the therapy led him to expect that "white chemotherapy" (based on the administration of docetaxel) had mild adverse reactions:

Some people said that this white chemotherapy attacks the body less, is simpler, is not going to cause nausea, and will be an easier process, but for Aline it was worse. $\left(4^{\text {th }}\right.$ interview)

The common sense of patients and relatives divides chemotherapy drugs for breast cancer treatment into "red," with a connotation of being stronger and having more severe adverse effects, and "white," which according to Francisco would be "less aggressive". ( $4^{\text {th }}$ interview)

There were moments of desperation and insecurity when they were faced with the severe pain presented by the wife:

We were terrified of the pain. We went to the emergency care unit and they gave her morphine. What do you think in a situation like this? She is a step from death! Morphine, for lay people like me, is for those on the verge of death. ( $3^{\text {rd }}$ interview)

In the popular culture, the use of the analgesic morphine is associated with patients who are "on the verge of death, "usually terminal cancer patients with chronic pain.

During the treatment, faced with adverse reactions stronger than expected and constant hospital admissions, it was necessary to interrupt chemotherapy after the penultimate cycle of treatment. This medical action was received with relief:

Things are better because she is not having as many reactions as she did before, pain in her body, all those things that chemotherapy caused. (6 $6^{\text {th }}$ interview)

\section{Dealing with the wife's stress}

During the chemotherapy process, Francisco reported that there were changes in his marital relationship:

Our marriage got more complicated after the diagnosis. $\left(4^{\text {th }}\right.$ interview) 
The relationship became troubled as a consequence of the "stress" of the wife after the beginning of chemotherapy, with more acute manifestations in the days leading up to the medicine infusion. "In the days leading up to the session her stress gets worse." He uses the metaphor "I keep walking on eggshells with her" to refer to the experienced situation. ( $4^{\text {th }}$ interview)

In his perception, his wife experiences constant feelings of dissatisfaction, "there was no pleasing her". According to him, he prefers to be alone and "stay cool"; he adopted the strategy of "constantly counting to ten" to avoid conflict ( $4^{\text {th }}$ interview). Thinking of the suffering experienced by the wife as a result of the disease and therapy, he said that he always "gives up" during the couple's arguments, "because I know that she is undergoing a treatment, "but he does not know how long he will be able to continue this behavior:

I have not reached my limit, but how long? The other partner keeps giving in, again and again, and gets sick of it. (6 $6^{\text {th }}$ interview)

These conflicts in his marital relationship can be illustrated by an excerpt from the field journal:

Today I witnessed an argument by the couple. It occurred in front of me and a secretary at the hospital. The wife got angry, raised her voice, and spoke impolitely to the participant in the study. The reason was the scheduling of the appointment with the odontology team, but I could not understand exactly what triggered the discussion. He was very embarrassed about the episode, but tried not to take it seriously and smiled apathetically to minimize the problem. (Field journal, 08/04/2015).

The repercussions in Francisco's life extended to his role as a male head of the household, which demanded that he begin to "look after the kids, take them to school and pick them up, shower and feed them, " often taking over the "household chores and preparation of the family meals, " tasks which were assigned to the wife before she got ill. ( $4^{\text {th }}$ interview)

In order to accompany his wife to medical appointments, chemotherapy sessions, and examinations, the participant needed "to be frequently absent from work, " which according to him "did not happen as often as it does now." In order to handle the care to his wife and children and manage household chores, in addition to his daily work, he reduced his participation in religious activities ("often, I set the work at church aside to stay with her"). This was social activity in which he used to be very assiduous before his wife's cancer diagnosis ( $6^{\text {th }}$ interview).

\section{Support networks in the therapy process}

During the whole chemotherapy process, the participant had the help of the family group in overcoming situations and difficulties, whether they involved transport to the hospital on chemotherapy days or help with the care of the children: "I get help from the family, especially her mother." (2nd interview)

Thus, the family was fundamental as a source of support and incentive to continue along his path. He also sometimes counted on the help of people from the religious community for care to his wife and children and household chores:

Her sisters from the church set a calendar to come here. We are getting help from the them from the church and my wife's family. (2 ${ }^{\text {nd }}$ interview)

Spirituality was an important source of support in his life, helping to maintain the hope for a cure:

In the beginning, the doctor said "Think positive, have faith, believe in God, and everything will be fine. If you begin thinking negatively now, things may get worse" $\left(5^{\text {th }}\right.$ interview)

In Francisco' case, spirituality was also considered a strategy to help overcome marital conflict. This element, practiced through faith and fulfillment of the promises made in the rituals of his religion, was supporting pillar in maintaining his marriage during conflict:

It is the commitment you have in marriage, which is called sealing; this commitment is between me, her, and God, and if it were not for this, I do not know what would happen $[\ldots]\left(6^{\text {th }}\right.$ interview)

\section{DISCUSSION}

The recognition of something different in the body, the "lump," led the patient and her spouse to seek help in the health system. Confirmation of a cancer diagnosis is not always efficient and quick. Structural, organizational, and bureaucratic problems in the Brazilian health system make it difficult to obtain an early cancer diagnosis. The delayed diagnosis, in this case, may also be associated with the young age of the wife, which decreased the likelihood that doctors would initially suspect breast cancer. This is because of a low incidence of this disease in this age group. Therefore, different factors contributed to this delay, involving social, cultural, and economic aspects, involving the patient, her relatives, and the health system. According to the biological specificities of the tumor, late diagnosis implies fewer chances of cure, more aggressive treatment, and mutilation. ${ }^{11-13}$

When Francisco learned of his wife's cancer diagnosis, he recognized it as a threat to her life, given that in his social context, cancer is a disease that is "hard to heal. "It is a socially stigmatized illness, described as "overwhelming," and is associated with suffering and death. Considered as an incurable disease, its name evokes fear. ${ }^{14,15}$ 
When the patient and her relatives received the news of diagnosis of a disease as "serious" as cancer, their lives became disorganized. Their routines became unsettled, which was reported as a feeling of "shock." Faced with the diagnosis, the patient and her relatives looked for an explanation, and tried to create a new meaning for the experienced process, described as "to learn something from it." The strategies adopted to deal with the wife's disease are individual characteristics, directly influenced by the spouse's cultural system. ${ }^{11}$

In his definition of the meaning of the chemotherapy treatment, the participant associated "chance of cure" with the cancer that affected his wife, although in his social context he recognized the disease as something to be feared, because it causes many reactions. Trust in chemotherapy is based on the sociocultural recognition that professional knowledge and the resources used in treatment can offer the longed-for "cure". In lay understanding, medical professionals do not make mistakes, because they can make the best decisions at the appropriate time. Patients and relatives consider themselves unable to make such decisions, which they consider too complex for their social context; in addition, they feel anguished and anxious because of the uncertainty of the results. ${ }^{12}$

It makes sense that perceptions of chemotherapy are pervaded by the belief that it can heal or kill. According to Francisco, "she has to do it, no matter what it can cause." Therefore, in his understanding, reactions must be endured, because they are less serious than the disease. There is a moral obligation to overcome adverse reactions and their limitations, as well as to strive to restore the normality of the body (cure). From Francisco's perspective, chemotherapy is a fundamental step toward reaching the cure. ${ }^{12}$

In the initial stages of chemotherapy, he needed to deal with the "surprises" of the adverse reactions that his wife presented, given that he had not been oriented about them. These reactions intensified his suffering and brought insecurity to his life. He often did not know how to deal with the situation. Francisco reported that it was expected that "white chemotherapy" would have milder effects than "red chemotherapy." This expectation resulted from his previous knowledge of the treatment, which he had acquired by observing his relatives and other cancer patients from his social circle. This situation illustrates the interaction of biomedical and cultural knowledge. ${ }^{12}$

In the social organization of masculinity, there are four ways to define what being a man is: hegemonic, subordinate, complicit, and marginalized. They are determined by behaviors and ways of acting and thinking when faced with different contexts of life. Hegemonic masculinity refers to patriarchy, which involves separation between behaviors considered masculine and feminine, and is characterized by dominance of men as bosses and subordination of women to men.

Complicit masculinity is defined as linked to hegemonic masculinity, but does not show complete incorporation of its elements. In complicit masculinity, there is interaction between men, women, and their social environment, without a need to establish who plays the dominant and subordinate roles. It is a more "complaisant" version of hegemonic masculinity, in which married men develop relationships of co-participation with their wives, rather than ruling them or displaying their authority. Marginalized masculinity is related to the supremacy of dominant classes or ethnic groups over subordinate categories, such as the rich and the poor, and employed and unemployed people. It is always associated with the authority of hegemonic masculinity of dominant groups. Subordinate masculinity pertains to domination and subordination between groups of men, for instance the domination of heterosexual men over homosexual ones, given that the latter are considered the inferior part of male hierarchy. ${ }^{16}$

These types of masculinity are involved in constant conflict, persuasion, and changes of standards, symbols, and references among themselves to reach and practice "hegemony," with the remaining groups being labeled as competitors or supporters of the leaders. This is what makes the types of masculinity, not only multiple at all times in multicultural societies, but also changeable over time and in different contexts of social power relationships. Consequently, depending on the type of male hegemony currently in practice, men will face differently care for wives with cancer undergoing chemotherapy. ${ }^{16,18}$

When observing the sociocultural characteristics of Francisco as a male, it was clear that hegemonic masculinity prevailed in his social group. He was the provider for his family, and had a job that supported this set of people. The wife was responsible for the care of their children and household chores. When the wife became ill, Francisco went through a redefinition of his masculinity, assuming behaviors typical of complicit masculinity. This was illustrated by the fact that he engaged in household duties such as "looking after the children and house" and was responsible for "preparing the meals for the family," given that these skills are not described as being characteristic of males, according to hegemonic masculinity. ${ }^{16}$

According to stereotypes, males are culturally conceived of as powerful, active, strong, self-confident, athletic, selfemployed workers, public people, and resistant to household chores. Behaviors such as looking after the children and the wife and carrying out household duties are attempts to escape stereotypes, which assume that they do not take care of other people. Within the scope of masculinity, attitudes like these are construed as hypo-masculine and a problem for the maintenance of this gender category. Faced with his wife's the disease and the new needs of the family, he assumed this new identity as a caretaker. The behaviors Francisco adopted during his wife's disease process are a cultural product, influenced by the way masculinity and gender are experienced in his social context. ${ }^{16,18}$

When he reported that he "gives in" during the couple's arguments to maintain their relationship and reduce his wife's stress, he violated the social principles that rule hegemonic masculinity, considering that this category is characterized by domination by men and subordination of women. ${ }^{16}$ This "give in" 
behavior depreciates the hegemonic masculine identity, putting Francisco in a situation of inferiority, submission, and femininity. Detachment from this masculinity leads to psychic suffering, severe stress, and even ischemic cardiac disease, according to the literature. ${ }^{4}$ This suffering may have been enhanced by his absence from his customary social activities, such as "the work at the church," in which he demonstrates his authority and supremacy over other men, given that he occupies a very high position in his religious system. Looking after his wife is an activity that is seen as feminine in the context of hegemonic masculinity. ${ }^{16}$

When analyzing the masculinity displayed by Francisco, it is possible to realize that it is not static, because there is continuous definition of the social being and his cultural structure. Masculinity is a culturally learned concept, so it is not a hereditary characteristic, but a social code that standardizes the conduct of people as men. ${ }^{17}$ Consequently, masculinity is not a set entity embedded in the bodies or personality traits of individuals, but a configuration of practices surrounding the position of men, which are expressed in their social actions. Therefore, they are multiple and can vary according to gender relationships in the same context. ${ }^{16-18}$

Spirituality is an important support network for patients and relatives during the disease process. Religious practices involving family members are fundamental to the success of conventional treatments and overcoming the disease, renewing hope and bringing security. ${ }^{11,19-21}$

Studies have shown that the experience of spouses of women with breast cancer is emotionally difficult and shocking. The disease contributes to significant changes in their routines after the diagnosis, in both the couple's relationship and family dynamics. ${ }^{22,23}$ The results of an integrative review, whose objective was to analyze experiences of spouses of women with breast cancer, pointed to changes in the relationships after the disease and impaired sexual activity. The spouses began to perform household chores and take over the care of the children. Their real feelings of sadness and fear of losing their wives were hidden, and support from religion was relevant during the process of coping with the illness. ${ }^{5}$

One study reported that psychological stress was higher among partners of patients with cancer than among patients themselves, and that partners were more likely to develop depression. In some cases, partners experienced fatigue, sleep problems, eating disorders, and frequency of pain episodes higher than that observed in patients. One year after the cancer diagnosis, partners of patients with cancer had significantly more mood disorders, reactions to severe stress, and ischemic cardiac disease in comparison with the number of episodes registered in the year before the diagnosis. ${ }^{4}$

\section{FINAL CONSIDERATIONS AND IMPLICATIONS FOR PRACTICE}

Explanatory models allowed understanding of the experience of the spouse of a woman with breast cancer undergoing chemotherapy. The meanings found in the present study corresponded to suffering caused by the diagnosis, and fear in the face of this severe disease. Once the diagnosis period was over, chemotherapy was seen as giving hope for a cure of the illness that was incurable, according to the spouse's cultural knowledge at that time. The treatment process involves many difficulties with multiple aspects, such as physical adverse reactions, bringing insecurity to the spouse's life. In this process, in order to be able to manage the wife's stress and reduce the couple's conflict, he needed to violate the rules of hegemonic masculinity, the predominant form in his social group, by subordinating to her and becoming complicit in household chores. He relied on religion and family as support networks to help him in this process.

The contributions of the present study to nursing practice are related to the rich knowledge produced about the experience of being the spouse of a woman with breast cancer undergoing chemotherapy. Qualitative studies do not propose interventions in health practices, but raise issues that encourage change and contribute to improvements in nursing care. The present study revealed that partners also go through intense suffering during the disease process of their wives, and should receive care and support from healthcare teams. Nursing teams that act in the context of care for women with breast cancer must involve spouses in their interventions, offering guidance oriented toward responding to doubts and wishes concerning chemotherapy, adverse effects, and how to handle them.

It is important to stress there have been no studies before the present research that had the objective of examining the meanings of this experience from the anthropological perspective, exploring the questions of masculinity that surround spouses. The results reported in other investigations have been limited to presenting the identified subjects, but did not explore the meanings associated with the experience.

One of the limitations of the present study was that the participant did not mention the sexual aspect of the relationship during the interviews, which could have been explored to expand the comprehension of the meaning of being the spouse of a woman with breast cancer. The authors emphasize the need to design new investigations with more participants, using different approaches, in an attempt to try to expand the perceptions of healthcare professionals regarding the experiences of partners in different contexts.

\section{REFERENCES}

1. Ministério da Saúde (BR). Instituto Nacional de Câncer José Alencar Gomes da Silva (INCA). Estimativa 2018. Incidência de Câncer no Brasil [Internet]. Rio de Janeiro: Instituto Nacional de Câncer José Alencar Gomes da Silva; 2018 [cited 2018 Feb 8]. Available from: http://www. inca.gov.br/estimativa/2018/sintese-de-resultados-comentarios.asp

2. Cecílio SG, Sales JB, Pereira NPA, Maia LLQGN. A visão do companheiro da mulher com histórico de câncer de mama. REME Rev Min Enferm [Internet]. 2013 Jan/Mar;17(1):23-31. Available from: http:// www.reme.org.br/artigo/detalhes/576 
3. Lôbo AS, Fernandes AFC, Almeida PC, Carvalho CM, Sawada NO. Qualidade de vida em mulheres com neoplasias de mama em quimioterapia. Acta Paul Enferm [Internet]. 2014; [cited 2017 Jan 27]; 27(6):554-9. Available from: http://www.scielo.br/pdf/ape/v27n6/19820194-ape-027-006-0554.pdf

4. Möllerberg ML, Sandgren A, Lithman T, Noreen D, Olsson H, Sjövall K. The effects of a cancer diagnosis on the health of a patient's partner: a population-based registry study of cancer in Sweden. Eur $\mathrm{J}$ Cancer Care (Engl) [Internet]. 2016 Sep;25(5):744-52. Available from: https:// www.ncbi.nlm.nih.gov/pubmed/?term=The+effects+of+a+cancer+dia gnosis+on+the+health+of+a+patient $\% E 2 \% 80 \% 99$ s+partner $\% 3 \mathrm{~A}+\mathrm{a}+$ population-based+registry+study+of+cancer+in+Sweden

5. Neris RR, Anjos ACY. Experience of spouses of women with breast cancer: an integrative literature review. Rev Esc Enferm USP [Internet]. 2014; [cited 2017 Jan 27]; 48(5):922-31. Available from: http://www. scielo.br/pdf/reeusp/v48n5/pt_0080-6234-reeusp-48-05-922.pdf

6. Çömez S, Karayurt Ö. We as Spouses Have Experienced a Real Disaster!: A Qualitative Study of Women With Breast Cancer and Their Spouses. Cancer Nurs [Internet]. 2016 Sep/Oct; 39(5):E19-28. Available from: https://www.ncbi.nlm.nih.gov/pubmed/?term=We+as+ Spouses+Have+Experienced+a+Real+Disaster!+Cancer+nursing.+2 016Sep-Otc\%3B+39(5)\%3A19-28

7. Langdon EJ, Wiik FB. Antropologia, saúde e doença: uma introdução ao conceito de cultura aplicado às ciências da saúde. Rev Latinoam Enferm [Internet]. 2010; [cited 2017 Jan 27]; 18(3):174-81. Available from: http://www.scielo.br/pdf/rlae/v18n3/pt_23

8. Stake RE. Case studies. In: Denzin NK, Lincoln YS, eds. Strategies of qualitative inquiry. Thousand Oaks (CA): Sage Publications; 2003. p. 134-64.

9. Boblin SL, Ireland S, Kirkpatrick H, Robertson K. Using Stake's qualitative case study approach to explore implementation of evidencebased practice. Qual Health Res [Internet]. 2013 Sep;23(9):1267-75. Available from: https://www.ncbi.nlm.nih.gov/pubmed/?term=Using+ Stake\%E2\%80\%99s+qualitative+case+study+approach+to+explore +implementation+of+evidence-based+practice

10. Braun V, Clarke V. Using thematic analysis in psychology. Qual Res Psychol [Internet]. 2006;3(2):77-101. Available from: https://www. tandfonline.com/doi/abs/10.1191/1478088706qp063oa

11. Lopes M, Nascimento LC, Zago MMF. Paradoxo da vida entre sobreviventes do câncer de bexiga e tratamentos. Rev Esc Enferm USP [Internet]. 2016; [cited 2017 Jan 27]; 50(2):224-31. Available from: http://www.scielo.br/pdf/reeusp/v50n2/pt_0080-6234reeusp-50-02-0224.pdf

12. Buetto LS, Zago MMF. Meanings of quality of life held by patients with colorectal cancer in the context of chemotherapy. Rev Latino Am Enferm [Internet]. 2015 May/Jun; [cited 2017 Jan 27]; 23(3):42734. Available from: http://www.scielo.br/pdf/rlae/v23n3/0104-1169rlae-0455-2572.pdf
13. Almeida TG, Comassetto I, Alves KMC, Santos AAP, Silva JMO, Trezza MCSF. Vivência da mulher jovem com câncer de mama e mastectomizada. Esc Anna Nery [Internet]. 2015 Jul/Sep; [cited 2018 Feb 8]; 19(3):432-8. Available from: http://www.scielo.br/pdf/ean/ v19n3/1414-8145-ean-19-03-0432.pdf

14. Wenger LM. 'Living under assault': men making sense of cancer. Eur $J$ Cancer Care (Engl) [Internet]. 2013 May;22(3):389-99. Available from: https://www.ncbi.nlm.nih.gov/pubmed/?term=Living+under+assault\% $3 \mathrm{~A}+$ men+making+sense+of+cancer.+Eur+j+cancer+care.+2013\%3B 22(3)\%3A389-399

15. Mardani-Hamooleh $\mathrm{M}$, Heidari $\mathrm{H}$. Cancer patients' effort to return to normal life: a hermaneutic study. Scand J Caring Sci [Internet]. 2017 Jun;31(2):351-8. Available from: https://www.ncbi.nlm.nih.gov/pubmed /?term=Cancer+patients\%E2\%80\%99+effort+to+return+to+normal+l $\mathrm{fe} \% 3 \mathrm{~A}+\mathrm{a}+$ hermaneutic+study.+Scand+J+Caring+Sci.+2016+Oct+11

16. Connell R. Masculinities. 2nd ed. Berkeley (CA): University of California Press; 2005.

17. Beynon J. Masculinities and culture. London: Open University Press; 2002.

18. Connell R. Gender: In: World Perspective. 2nd ed. Cambridge (UK): Polity; 2012.

19. Anjos ACY, Zago MMF. Ressignificação da vida do cuidador do paciente idoso com câncer. Rev Bras Enferm [Internet]. 2014 Sep/Oct;67(5)7528. Available from: http://www.scielo.br/pdf/reben/v67n5/0034-7167reben-67-05-0752.pdf

20. Aldaz BE, Treharne GJ, Knight RG, Conner TS, Perez D. 'It gets into your head as well as your body': The experiences of patients with cancer during oncology treatment with curative intent. J Health Psychol [Internet]. 2018 Jan;23(1):3-16. Available from: https://www.ncbi.nlm. nih.gov/pubmed/?term=.+It+gets+into+your+head+as+well+as+your +body $\% 3 \mathrm{~A}+\mathrm{The}+$ experiences+of+patients+with+cancer+during+on cology+treatment+with+curative+intent.+J+Health+Psychol.+2016+ oct+5

21. Nascimento LC, Santos TFM, Oliveira FCS, Pan R, Flória-Santos M, Rocha SMM. Spirituality and religiosity in the perspectives of nurses. Texto Contexto Enferm [Internet]. 2013 Jan/Mar; [cited 2017 Jan 27]; 22(1):52-60. Available from: http://www.scielo.br/pdf/tce/v22n1/07.pdf

22. Zahlis EH, Lewis FM. Coming to grips with breast cancer: the spouse's experience with his wife's first six months. J Psychosoc Oncol [Internet] 2010;28(1):79-97. Available from: https://www.ncbi.nlm.nih.gov/pubm ed/?term=Coming+to+grips+with+breast+cancer\%3A+the+spouses+ experience+with+his+wifes+first+six+months

23. Dugglebly W, Bally J, Cooper D, Doell H, Thomas R. Engaging hope: the experiences of male spouses of women with breast cancer. Onco Nurs Forum [Internet]. $2012 \mathrm{Jul} ; 39(4): 400-6$. Available from: https:// www.ncbi.nlm.nih.gov/pubmed/?term=Engaging+hope\%3A+the+ex periences+of+male+spouses+of+women+with+breast+cancer.+Onc ol+Nurs+Forum.+2012\%3B39(4)\%3A400-6 